\title{
Analisis Strategi Forum Kewaspadaan Dini Masyarakat (FKDM) atas Cegah Dini dalam Penanganan Konflik Sosial di Provinsi Dki Jakarta Tahun 2019
}

\author{
Dwi Agustina ${ }^{a, 1}$, Edy Mulyadi ${ }^{\text {b,2 }}$ \\ 1,2 Institut Ilmu Sosial dan Manajemen STIAMI, Jakarta, Indonesia \\ 1 dwiagustina1808@gmail.com, 2 edynayla02@gmail.com@gmail.com \\ * corresponding author
}

\section{ARTICLE INFO}

Article history

Received 2020-02-02

Revised 2020-05-05

Accepted 2020-06-22

\section{Keywords}

strategy, forum kewaspadaan dini

masyarakat (FKDM), social conflict

\begin{abstract}
is obliged to facilitate it. A good role of the Community Early Awareness Forum or Forum Kewaspadaan Dini Masyarakat (FKDM) followed up by the government can save the community from security threat or disaster and minimize losses by anticipating the security threats and disaster. This research uses qualitative approach. Concept operationalization in this research refers to the used strategy, the SWOT analysis. The FKDM strategies in social conflict early prevention are: 1) inserting early warning system by increasing institutional capacities which include three elements; government, private sector, community through dialogue, 2) National Unity and Politics Agency or Badan Kesatuan Bangsa dan Politik (Kesbangpol) of DKI Jakarta actively making dialogue persuasively and finding solution, 3) budgeting of conflict handling according to the Government Regulation gives opportunity to strengthen community resilience to protect the community, encourage community participation, handle social conflict, and preserve local wisdom to maintain peace.
\end{abstract}

\section{PENDAHULUAN}

Jakarta secara umum Ibukota Negara menjadi pusat perhatian dari segala hal urusan diantaranya pusat pemerintahan, pusat kegiatan ekonomi, pusat keuangan dan jasa serta tempat kedudukan hampir seluruh perangkat pemerintahan tingkat pusat, perwakilan negara-negara asing, pusat perusahaan multi nasional dan gerbang utama wisatawan manca negara. Untuk itu tidaklah heran apabila Jakarta memiliki peran ganda yang sangat strategis dalam menentukan arah kebijakan secara lokal maupun nasional dan mempengaruhi situasi dan kondisi keamanan, ketentraman dan ketertiban masyarakat (kamtibmas) seperti dibidang ideologi, politik, ekonomi, sosial budaya dan keamanan bagi seluruh wilayah Indonesia, kawasan Asia bahkan dunia.

Peran serta masyarakat dalam urusan keamanan, ketentraman dan ketertiban tersebut dapat diperluas melalui wadah Forum Kewaspadaan Dini Masyarakat (FKDM) yang dibentuk sebagai upaya untuk menjawab kebutuhan dalam mengakselerasikan terbangunnya budaya waspada di masyarakat. Forum Kewaspadaan Dini Masyarakat (FKDM) dibentuk berdasarkan Peraturan Menteri Dalam Negeri Nomor 12 Tahun 2006 tentang Kewaspadaan Dini Masyarakat di Daerah, dibentuk mulai dari tingkat provinsi, kabupaten/ kota, kecamatan, sampai di tingkat desa/ kelurahan.

Salah satu peran Forum Kewaspadaan Dini Masyarakat (FKDM) di masyarakat dalam bidang ketertiban dan keamanan yaitu dengan terlibat langsung dalam kegiatan Siskamling yang bertujuan untuk ikut serta mengamankan lingkungan, selain itu Forum Kewaspadaan Dini Masyarakat (FKDM) ikut membantu dalam memberikan Informasi mengenai hal-hal yang bersifat mengganggu keamanan dan kenyamanan masyarakat seperti tawuran, pencurian, teror/ begal hingga memberikan Informasi wilayah yang kebanjiran maupun Kebakaran. Dalam bidang pendidikan untuk mencegah konflik dan kekerasan antar sesama warga yang di dukung oleh Dinas Pendidikan, Institusi - institusi pendidikan berbasis agama serperti pesantren, dengan melalukan edukasi bagi warga masyarakat yang tersegregasi menurut identitas etnis, agama dan golongan. Berperan serta dalam bidang kebudayaan, dalam hal ini upaya pemberdayaan dan pembangunan ketahanan di tingkat akar rumput. Pencegahan konflik dan 
kekerasan dilakukan dengan menjalankan proses kebudayaan yang bertujan merekatkan hubungan antar kelompok diantaranya: kelompok Tionghoa, Kelompok Madura, Kelompok Pribumi dan sering melibatkan warga dari etnis dan agama lain dalam kegiatan Seni dan Budaya mereka. Dengan cara itu di harapkan pengenalan dan pertukaran antar budaya dapat menghilangkan sekat - sekat antar kelompok di masyarakat. Bersama dengan program pendidikan, kegiatan - kegiatan kebudayaan, seperti pegelaran kesenian secara tidak langsung memiliki fungsi edikatif dan memberikan pemahaman tentang nilai nilai budaya yang di anut kelompok lain. Permberdayaan masyarakat dibidang ekonomi, dalam hal ini berperan penting dalam pemberdayaan perekonomian tiap - tiap kelompok masyarakat.

Pentingnya penelitian ini yaitu untuk mengetahui bagaimana peran dan strategi Forum Kewaspadaan Dini Masyarakat (FKDM) dalam cegah dini terhadap Ancaman, Tantangan, Hambatan dan gangguan (ATHG) di Provinsi DKI Jakarta. Dari penelitian terdahulu dapat dilihat hanya penanganan pasca konflik yang dibahas, tetapi penelitian ini menekankan pada pencegahan konflik yang akan terjadi.

\section{KERANGKA TEORITIS}

Rangkuti (2013:183) berpendapat bahwa strategi adalah perencanaan induk yang komprehensif, yang menjelaskan bagaimana perusahaan akan mencapai semua tujuan yang telah di tetapkan berdasarkan misi yang telah di tetapkan sebelumnya.

Analisis SWOT pertama kali diperkenalkan oleh Albert S Humphrey pada tahun 1960-an dalam memimpin proyek riset di Stanford Research Institute yang menggunakan data dari perusahaanperusahaan Fortune 500. Menurut Rachmat (2014:285) analisis SWOT terdiri dari 4 komponen dasar yaitu:

a. Strength (Kekuatan) atau disingkat dengan "S", yaitu karakteristik organisasi ataupun proyek yang memberikan kelebihan / keuntungan dibandingkan dengan yang lainnya.

b. Weakness (Kelemahan) atau disingkat dengan "W", yaitu karakteristik yang berkaitan dengan kelemahan pada organisasi ataupun proyek dibandingkan dengan yang lainnya.

c. Opportunities (Peluang) atau disingkat dengan "O", yaitu Peluang yang dapat dimanfaatkan bagi organisasi ataupun proyek untuk dapat berkembang di kemudian hari.

d. Threats (Ancaman) atau disingkat dengan "T", yaitu Ancaman yang akan dihadapi oleh organisasi ataupun proyek yang dapat menghambat perkembangannya.

Dari keempat komponen dasar tersebut, Strength (kekuatan) dan Weakness (Kelemahan) adalah faktor internal organisasi/ proyek itu sendiri, sedangkan Oppoturnities (Peluang) dan Threats (Ancaman) merupakan faktor eksternal yang mempengaruhi perkembangan organisasi ataupun proyek. Oleh karena itu, Analisis SWOT juga sering disebut dengan Analisis Internal-Eksternal (Internal-External Analisis) dan Matriks SWOT juga sering dikenal dengan Matrix IE (IE Matrix).

Metode analisis SWOT dianggap sebagai metode analisis yang paling dasar, yang berguna untuk melihat suatu topik atau permasalahan dari empat sisi yang berbeda. Hasil analisis adalah menambah keuntungan dari peluang yang ada, dengan mengurangi kekurangan dan menghindari ancaman

Pergub No. 138 Tahun 2019 tentang Penyelengaraan Kewaspadaan Dini di Provinsi Daerah Ibu Kota Jakarta. Dalam Pergub tersebut disebutkan bahwa kewaspadaan dini adalah serangkaian upaya/ tindakan untuk menangkal segala potensi ancaman, tantangan, hambatan dan gangguan dengan meningkatkan pendeteksian dan pencegahan dini.

Dalam Pergub tersebut juga disebutkan Tim Kewaspadaan Dini Provinsi Daerah Khusus Ibu Kota Jakarta adalah tim yang dibentuk oleh gubernur untuk membantu pelaksanaan tugas gubernur dalam pelaksanaan kewaspadaan dini di Pemerintah Provinsi DKI Jakarta. Sedangkan Forum Kewaspadaan Dini Masyarakat (FKDM) adalah wadah bagi elemen masyarakat yang dibentuk dalam rangka menjaga dan memelihara kewaspadaan dini masyarakat. 


\section{METODE PENELITIAN}

Penelitian ini mengunakan pendekatan kualitatif. Dilihat dari segi tempat penelitian, penelitian ini termasuk dalam jenis penelitian lapangan yang berusaha mengadakan penelitian ke lokasi secara langsung dengan maksud memperoleh data-data yang akurat, cermat dan lebih lengkap. Operasionalisasi konsep dalam penelitian ini mengacu pada strategi yang digunakan yaitu dengan menggunakan Analisis SWOT. Analisis SWOT merupakan bentuk analisis situasi dan kondisi yang bersifat deskriptif (memberi gambaran).

Dalam menentukan informan digunakan teknik Purposive Sampling. Informan untuk penelitian ini adalah dari Badan Kesatuan Bangsa dan Politik Provinsi DKI Jakarta yaitu orang yang menangani Forum Kewaspadaan Dini Masyarakat (FKDM) dan yang menangani konflik sosial, sehingga penulis mendapatkan informasi dan data yang komprehensif. Informan tersebut yaitu: Ketua Forum Kewaspadaan Dini Masyarakat (FKDM), Kepala Badan Kesatuan Bangsa dan Politik Provinsi DKI Jakarta, Kepala Sub Bidang Kewaspadaan Dini Badan Kesatuan Bangsa dan Politik Provinsi DKI Jakarta.

\section{HASIL DAN PEMBAHASAN}

Dalam analisis SWOT Faktor-faktor internal dan eksternal saling berhubungan dan keterkaitan satu dengan yang lainnya, dari keterkaitan dan hubungan tersebut dapat diperoleh strategi yang tepat untuk menerapkan kebijakan. Hubungan dan keterkaitan antara faktor-faktor internal dan eksternal seperti berikut:

\section{Strategi kekuatan dan Peluang (S+O)}

Strategi keterkaitan kekuatan dan peluang harus melihat beberapa faktor-faktor yang ada sehingga strategi tersebut dapat dijadikan Penanganan Konflik Sosial di Provinsi DKI Jakarta. Dalam pelaksanaan cegah dini dalam penanganan konflik sosial di Provinsi DKI Jakarta diperlukan adanya anggaran, jika mengacu Peraturan Pemerintah Republik Indonesia Nomor 2 Tahun 2015 Tentang Peraturan Pelaksanaan Undang-Undang Nomor 7 Tahun 2012 Tentang Penanganan Konflik Sosial BAB VII; Pendanaan Penanganan Konflik Bagian Kesatu pasal 78.

Kesimpulan dari faktor kekuatan dan peluang adalah pertama adanya peningkatan kapasitas kelembagaan dan adanya dialog kepada masyarakat dapat mencegah konflik dalam bidang pendidikan, kebudayaan serta pemberdayaan masyarakat. Yang kedua dengan adanya pendanaan penanganan konflik yang diatur dalam Peraturan Pemerintah akan memberikan peluang penguatan berketahanan komunitas yang memilki tujuan melindungi masyarakat, mendorong partisipasi masyarakat warga masyarakat, mengendalikan konflik sosial serta memelihara kearifan lokal yang digunakan untuk memelihara perdamaian.

\section{Strategi kelemahan dan Peluang $(\mathrm{W}+\mathrm{O})$}

Strategi keterkaitan antara kelemahan dan peluang harus melihat beberapa faktor-faktor yang ada serta merumuskan peluang untuk mengatasi kelemahan di wilayah DKI Jakarta.

Adanya faktor yang menjadi hambatan dan kendala yang dihadapi Badan Kesatuan Bangsa dan Politik Provinsi DKI Jakarta dalam penanganan konflik sosial di Provinsi DKI Jakarta, yaitu munculnya konflik dan isi dari tuntutan berlebihan sehingga Badan Kesbangpol tidak memiliki kapasitas untuk segera memutuskan tuntutan dari para pelaku konflik memunculkan peluang FKDM atas cegah dini dalam penanganan konflik sosial di Provinsi DKI Jakarta .

Kesimpulan dari faktor kelemahan dan faktor peluang yang pertama adalah munculnya konflik dan isi dari tuntutan berlebihan yang membuat Badan Kesbangpol tidak memiliki kapasitas untuk segera memutuskan tuntutan dari para pelaku konflik memunculkan peluang FKDM atas cegah dini dalam penanganan konflik sosial di Provinsi DKI Jakarta yang dapat meningkatkan perannya dalam bidang pendidikan, kebudayaan dan melaksanakan pemberdayaan dalam bidang ekonomi, dengan berperannya FKDM dari semua bidang sehingga akan memudahkan Badan Kesbangpol dalam memutuskan tuntutan dari pelaku konflik yang dimungkinkan konflik terjadi pada salah satu bidang tersebut, sedangkan yang kedua adalah adanya masalah internal DKI Jakarta serta tuntutan 
yang berubah-ubah dari pelaku sehingga Anggota FKDM belum segera memberikan solusi yang terbaik akan memberikan peluang FKDM dalam berperan mengatasi konflik di berbagai bidang.

\section{Strategi kekuatan dan Ancaman (S+T)}

Strategi keterkaitan antara kekuatan dan ancaman harus melihat faktor-faktor yang bertujuan meredam ancaman dengan memakai kekuatan yang ada dan menghindari ancaman.

Kesimpulan dari faktor kekuatan dan kelemahaan adalah pertama dengan unsur sistem peringatan dini (early warning sisytem) yaitu peningkatan kapasitas kelembagaan yang terdiri dari tiga unsur yaitu Kapasitas pemerintah baik pusat maupun daerah, kapasitas sektor swasta, kapasitas komunitas masyarakat maka dapat mengatasi terjadinya konflik sosial yang menyebabkan hilangnya rasa aman dan menciptakan rasa takut masyarakat serta kerusakan lingkungan, kerusakan pranata sosial, kerugian harta benda, korban jiwa dan trauma psikologis juga dapat mengatasi ancaman terhadap kepemilikan sumber daya alam yang pengelolaannya tidak memperhatikan kepentingan masyarakat setempat. Yang kedua tindakan pencegahan konfilk yang dilakukan Badan Kesbangpol DKI Jakarta berperan aktif mengajak dialog secara persuasif dan mendengarkan keluhan para pihak dan mencari solusi yang terbaik untuk semua pihak dapat mengatasi ancaman yang disebabkan keaneka ragaman suku bangsa, budaya dan agama serta mengatasi ancaman berupa kemunculan gerakan radikalisme dalam negeri pada satu sisi dan pada sisi lain hidup dalam tatanan dunia yang terbuka dengan pengaruh asing yang sangat rawan dan berpotensi menimbulkan konflik.

\section{Strategi kelemahan dan Ancaman (W+T)}

Strategi keterkaitan kelemahan dan ancaman harus melihat dari faktor-faktor yang dimana kelemahan dan ancaman tersebut bisa di kontrol untuk mengurangi dampak negatif yang berimbas pada jalannya pemerintahan, ekonomi maupun sosial.

Kesimpulan dari faktor kelemahan dan ancaman dimana adanya kelemahan dalam penanganan konflik sosial di Provinsi DKI Jakarta yaitu munculnya konflik dan isi dari tuntutan berlebihan, dapat menimbulkan beeberapa ancaman yaitu hilangnya rasa aman serta memunculkan rasa takut pada masyarakat juga adanya rasa ketidakadilan dari masyarakat dikarenakan Badan Kesbangpol yang tidak memiliki kapasitas untuk segera memutuskan tuntutan dari para pelaku konflik sehingga tidak mampu membantu masyarakat yang berkonflik dengan cepat.

\section{KESIMPULAN}

Berdasarkan hasil penelitian dan pembahasan yang telah diuraikan dan dirumuskan dalam penelitian yang penulis lakukan maka diperoleh kesimpulan sebagai berikut:

1. Strategi Forum Kewaspadaan Dini Masyarakat (FKDM) atas cegah dini dalam penanganan konflik sosial di Provinsi DKI Jakarta yaitu: 1). Memasukkan unsur sistem peringatan dini (early warning sisytem), yaitu melalui peningkatan kapasitas kelembagaan yang terdiri dari tiga unsur yaitu kapasitas pemerintah, kapasitas sektor swasta, kapasitas komunitas masyarakat melalui dialog kepada masyarakat; 2). Tindakan pencegahan konfilk dalam tahap ini Badan Kesbangpol DKI Jakarta berperan aktif mengajak dialog secara persuasif dan mendengarkan keluhan para pihak dan mencari solusi yang terbaik untuk semua pihak; 3). Adanya pendanaan penanganan konflik yang diatur dalam Peraturan Pemerintah akan memberikan peluang penguatan ketahanan komunitas yang memilki tujuan melindungi masyarakat, mendorong partisipasi masyarakat warga masyarakat, mengendalikan konflik sosial serta memelihara kearifan lokal yang digunakan untuk memelihara perdamaian.

2. Hambatan Forum Kewaspadaan Dini Masyarakat (FKDM) atas cegah dini dalam penanganan konflik sosial di Provinsi DKI Jakarta antara lain: 1). Badan Kesbangpol tidak memiliki kapasitas untuk segera memutuskan tuntutan dari para pelaku konflik; 2). Tingkat pendidikan masyarakat yang masih rendah, lokasi rawan padat penduduk terutama daerah padat yang rawan narkoba, sarana dan prasarana yang terbatas; 3). Konflik tidak berangkat akar masalah; 4). Penanganan konflik bersifat proyek dari masing-masing SKPD/UKPD dan tidak terkoordinasi dan terintegrasi dengan baik. 
3. Upaya yang Forum Kewaspadaan Dini Masyarakat (FKDM) lakukan atas cegah dini dalam penanganan konflik sosial di Provinsi DKI Jakarta yaitu: 1). Dengan berperan dalam berbagai bidang, yaitu bidang pendidikan, kebudayaan dan pemberdayaan masyarakat dibidang ekonomi; 2). Melaksanakan pemantauan wilayah dan melaporkannya setiap hari secara berjenjang; 3). Partisipasi masyarakat dalam pelaksanaan cegah dini dalam penanganan konflik sosial di Provinsi DKI Jakarta khususnya pada tingkat RT sehingga akan memudahkan penanganan konflik di masyarakat

\section{DAFTAR PUSTAKA}

Ahmad Tanzeh. 2011. Metodologi Penelitian Praktis. Yogyakarta: Teras

Bambang Wahyudi. 2012. Manajemen Sumber Daya Manusia. Bandung: Sulita.

Bambang Riyanto. 2013. Dasar-Dasar Pembelanjaan Perusahaan. Edisi. Keempat.Yogyakarta: BPFE.

Dewi, Irra Chrisyanti. 2011. Pengantar Ilmu Administrasi. Jakarta: PT Prestasi Pustaka Raya.

Harsono. 2011. Etnografi Pendidikan sebagai Desain Penelitian Kualitatif. Surakarta: Universitas Muhammadiyah Surakarta

Miles, Matthew B. \& A. Michael Huberman. 2009. Analisis Data Kualitatif. Jakarta: UI-Press.

Moleong Lexsi. 2015. Prosedur Penelitian Kualitatif. Bandung: Alfabeta

Peraturan Kementerian dalam Negeri No. 46 Tahun 2019 tentang Perubahan Atas Peraturan Menteri Dalam Negeri Nomor 2 Tahun 2018 Tentang Kewaspadaan Dini Di Daerah

Peraturan Gubernur No. 138 Tahun 2019 tentang Penyelengaraan Kewaspadaan Dini di Provinsi Daerah Ibu Kota Jakarta.

Rachmat. 2014. Manajemen Strategik. Bandung: Pustaka Setia.

Rachmat. 2013. Filsafat Administrasi. Bandung: Pustaka Setia.

Rangkuti, Freddy. 2013. Analisis SWOT: Teknik Membedah Kasus Bisnis. Jakarta: PT. Gramedia Pustaka Utama.

Siagian. Sondang P. 2010. Filsafat Administrasi. Jakarta: PT Bumi. Aksara.

Stephen, Robbins. 2015. Perilaku Organisasi. Jakarta: Salemba Empat

Sugiyono. 2017. Metode Penelitian Kuantitatif, Kualitatif, dan R\&D. Bandung : Alfabeta.

Thoha, Miftah. 2010. Ilmu Administrasi Publik Kontemporer. Jakarta: Kencana.

Thoha, Miftah. 2012. Prilaku Organisasi Konsep Dasar dan Implikasinya. Jakarta: Rajawali Pers

Silalahi, Ulber. 2010. Metode Penelitian Sosial. Jakarta: Refika Aditama

Winarno Surakhmad. 2015. Pengantar Penelitian Ilmiah. Bandung: Tarsito 